\title{
PENERAPAN DISCOVERY LEARNING KOMBINASI VIDEO UNTUK MENINGKATKAN HASIL BELAJAR MATEMATIKA SISWA
}

\author{
Etik Nuroidah ${ }^{1}$, Syarifatul Maf'ulah ${ }^{2}$ \\ 1SMP Negeri 2 Peterongan, Jombang, Indonesia 61481 \\ 2Pendidikan Matematika, STKIP PGR Jombang, Jombang, Indonesia 61418 \\ email korespondensi : syarifatul.m@gmail.com
}

Diterima : (09-11-2021), Revisi: (20-12-2021), Diterbitkan : (25-12-2021)

\begin{abstract}
ABSTRAK
Penelitian ini bertujuan untuk meningkatkan hasil belajar matematika siswa melalui discovery learning yang dikombinasikan dengan video. Penelitian ini merupakan Penelitian Tindakan Kelas (PTK) dengan subjek penelitian siswa kelas IX-B SMP Negeri 2 Peterongan sebanyak 32 siswa. Instrumen penelitian ini adalah lembar observasi aktivitas guru, lembar observasi aktivitas siswa, dan tes. Indikator keberhasilan penelitian ini adalah : (1) aktivitas guru dan aktivitas siswa selama pembelajaran berada pada kategori minimal baik; dan (2) ketuntasan hasil belajar siswa secara klasikal mencapai $\geq 80 \%$. Siswa dikatakan tuntas secara individu apabila memperoleh skor hasil tes hasil belajar $\geq 75$. Hasil observasi pada siklus 1 menunjukkan persentase aktivitas guru mencapai 79\% (baik), persentase aktivitas siswa mencapai $67 \%$ (cukup baik), dan secara klasikal sebesar 75\% siswa tuntas hasil belajarnya. Sedangkan pada siklus 2, aktivitas guru mencapai $86 \%$ (sangat baik), aktivitas siswa sebesar $86 \%$ (sangat baik), dan secara klasikal sebesar $88 \%$ siswa tuntas hasil belajarnya. Artinya telah terjadi peningkatan hasil belajar matematika siswa pada siklus ke-2, sehingga penerapan discovery learning kombinasi video dapat meningkatkan hasil belajar matematika siswa.

Kata kunci: discovery learning kombinasi video, hasil belajar
\end{abstract}




\begin{abstract}
This study aims to improve students' mathematics learning outcomes through discovery learning combined with video. This research is a Classroom Action Research (CAR) with 32 students as the subject of class IX-B SMP Negeri 2 Peterongan. The instruments of this research are teacher activity observation sheets, student activity observations sheet, and test. The indicators of the success of this research are : (1) teacher and student activities during learning are in the minimally good category; and (2) mastery of student learning outcomes classically reached $80 \%$. Students are said to be completed individually if they get a score of learning outcomes test results 75 . The results of observations in cycle 1 show the percentage of teacher activity reaches $79 \%$ (good), the percentage of student activity reaches 67\% (good enough), and classically $75 \%$ of students complete their learning outcomes. While in cycle 2, teacher activity reached $86 \%$ (very good), student activity was $86 \%$ (very good), and classically $88 \%$ of students completed their learning outcomes. This means that there has been an increase in students' mathematics learning outcomes in the second cycle, so that the application of discovery learning combined with video can improve students' mathematics learning outcomes.
\end{abstract}

Key words : discovery learning combined with video, learning outcomes

\title{
Pendahuluan
}

Adanya pandemi COVID-19 berimbas pada pembelajaran di sekolah dengan pelaksanaa secara online (daring). Salah satunya di SMP Negeri 2 Peterongan. Pembelajaran daring (online) di SMP Negeri 2 Peterongan hingga saat ini masih berpusat pada guru dalam bentuk pengiriman materi atau tugas di grup WhatsApp. Efeknya, mayoritas siswa cenderung pasif dan hanya siswa tertentu yang memberikan respon terhadap tugas tersebut. Efek tersebut menunjukkan bahwa siswa belum maksimal untuk berpikir karena belum terbiasa aktif dalam pembelajaran dan terbiasa tergantung pada materi yang disampaikan guru. Sehingga pembelajaran daring dipandang kurang efektif karena kurang melibatkan pengembangan kemampuan berpikir dan bertindak secara kritis, kurang dapat mengembangkan kemampuan berkolaborasi dalam proses belajar, serta siswa kurang termotivasi dan kurang bertanggung jawab terhadap proses belajarnya.

Pembelajaran daring memberikan tantangan tersendiri khususnya bagi guru. Bagi guru yang belum dapat beradaptasi, umumnya pembelajaran daring dilakukan dengan pemberian materi, pengiriman tugas dan penagihan tugas kepada siswa tanpa terjadi interaksi yang mendorong siswa untuk mencari tahu konsep pembelajarannya. Akibatnya muncul kesan pembelajaran daring adalah 
pemberian tugas oleh guru kepada siswa yang mengakibatkan bertumpuknya tugas bagi siswa, khususnya yang kurang rajin selama pembelajaran daring. Observasi awal yang dilakukan di SMP Negeri 2 Peterongan menunjukkan bahwa hasil belajar siswa kelas IX-B SMP Negeri 2 Peterongan pada materi kekongruenan dan kesebangunan masih pada kategori rendah. Hanya sekitar 59\% siswa mendapatkan nilai di atas KKM dengan KKM 75.

Untuk itu diupayakan suatu inovasi pembelajaran dengan harapan dapat memperbaiki mutu pembelajaran dan meningkatkan hasil belajar siswa. Inovasi tersebut dilakukan dengan menerapkan discovery learning kombinasi video. Disccovery learning adalah proses pembelajaran yang berfokus pada penemuan, yaitu siswa mencari sendiri materi yang akan dipelajari, terlibat secara aktif dalam proses pembelajaran dengan menggunakan pengalaman-pengalaman yang dimilikinya, serta menemukan beberapa konsep dan prinsip (Hosnan, 2014; Anam, 2016; Ariyana, 2019).

Discovery learning merupakan suatu pembelajaran yang melibatkan siswa dalam pemecahan masalah untuk pengembangan pengetahuan dan ketrampilan (Adhar, 2012). Ciri utama model discovery learning adalah (1) berpusat pada siswa; (2) mengeksplorasi dan memecahkan masalah untuk menciptakan, menghubungkan, dan menggeneralisasi pengetahuan; serta (3) kegiatan untuk menggabungkan pengetahuan baru dan pengetahuan yang sudah ada (Kristin, 2016). Karakteristik dari discovery learning dapat melatih kemampuan pemecahan masalah siswa (Pangaribowo et al., 2017; Widiadnyana et al., 2014). Pemecahan masalah sendiri merupakan ruhnya pembelajaran matematika (Maf'ulah \& Juniati, 2019; Maf'ulah \& Juniati, 2020).

Kelebihan model discovery learning diantaranya adalah : (1) membantu siswa untuk memperbaiki dan meningkatkan keterampilan-keterampilan dan proses-proses kognitif; (2) memungkinkan siswa berkembang dengan cepat dan sesuai dengan kecepatannya sendiri; (3) meningkatkan tingkat penghargaan pada siswa karena adanya unsur berdiskusi; (4) mampu menimbulkan perasaan senang dan bahagia karena siswa berhasil melakukan penelitian; dan (5) membantu siswa menghilangkan skeptisme (keragu-raguan) karena mengarah pada kebenaran yang final dan tertentu atau pasti (Yuliana, 2019).

Video merupakan media elektronik yang mampu menggabungkan teknologi audio dan visual secara bersama sehingga menghasilkan suatu tayangan yang 
dinamis dan menarik (Yudianto, 2017). Manfaat media video menurut Prastowo (2012) antara lain : memberikan pengalaman yang tak terduga kepada siswa; memperlihatkan secara nyata sesuatu yang pada awalnya tidak mungkin bisa dilihat; menganalisis perubahan dalam periode waktu tertentu; memberikan pengalaman kepada siswa untuk merasakan suatu keadaan tertentu, dan menampilkan presentasi studi kasus tentang kehidupan sebenarnya yang dapat memicu diskusi siswa.

Terdapat 6 tahap (langkah-langkah) discovery learning kombinasi video, yaitu : (1) pemberian rangsangan, yaitu guru memberi rangsangan dan mengajukan pertanyaan; (2) identifikasi masalah, yaitu guru meminta siswa untuk mengajukan pertanyaan berkaitan dengan permasalahan yang disampaikan guru; (3) pengumpulan data, yaitu guru memberi kesempatan siswa untuk membaca berbagai sumber dan mengirim video youtube melalui tautan; (4) pengolahan data, yaitu guru membimbing siswa saat siswa mengolah data; (5) pembuktian, yaitu guru meminta siswa berdiskusi dalam menyelesaikan masalah melalui forum google classroom atau grup WA; (6) penarikan kesimpulan, yaitu guru bersama siswa membuat kesimpulan terhadap materi yang telah dipelajari. Pemanfaatan video dilaksanakan pada langkah ketiga discovery learning.

Siswa diharapkan bersungguh-sungguh dalam pembelajaran daring dan tidak sekedar mengerjakan dan mengirim tugas saja. Discovery learning kombinasi video diharapkan mampu membantu siswa untuk mengembangkan, memperbanyak kesiapan serta penguasaan keterampilan dalam proses kognitif siswa. Siswa diharapkan dapat memperoleh pengetahuan yang bersifat sangat individual sehingga dapat mendalam tertinggal dalam jiwa siswa tersebut. Selain itu juga dapat membangkitkan kegairahan belajar siswa, mampu memberikan kesempatan pada siswa untuk berkembang dan maju sesuai dengan kemampuan masing-masing, mampu mengarahkan cara belajar siswa sehingga lebih memiliki motivasi yang kuat untuk belajar lebih giat, membantu siswa untuk memperkuat dan menambah kepercayaan pada diri sendiri dengan proses penemuan sendiri dibantu video sebagai media sekaligus sumber belajar. Pada akhirnya dengan kegiatan ini diharapkan pembelajaran menjadi lebih bermakna, siswa lebih memahami materi dan memperoleh hasil belajar yang memuaskan dalam pembelajaran yang dilakukan secara daring. 


\section{Metode Penelitian}

Penelitian ini merupakan penelitian tindakan kelas (PTK). Subjek penelitian ini adalah siswa kelas IX-B SMP Negeri 2 Peterongan sebanyak 32 siswa. Penelitian ini dilaksanakan pada bulan Januari 2021 sampai Maret 2021. PTK dilaksanakan sebanyak dua siklus. Tiap siklus terdiri tahapan: perencanaan, pelaksanaan, observasi, dan refleksi. Instrumen penelitian ini adalah : lembar observasi aktivitas guru, lembar observasi aktivitas siswa, dan tes hasil belajar.

Data hasil pengamatan aktivitas guru dalam mengelola pembelajaran dengan discovery learning kombinasi video dianalisis dengan aturan berikut (Muttaqin \& Azmi, 2020).

$$
P T=\frac{n}{N} \times 100 \%
$$

Keterangan : $P T$ : Persentase keterlaksanaan

$n$ :Jumlah skor yang diperoleh

$N$ : Jumlah skor maksimal

Adapun kriteria keterlaksanaan pembelajaran discovery learning kombinasi video ditunjukkan dalam tabel berikut.

Tabel 1 Kriteria Keterlaksanaan Pembelajaran Discovery Learning Kombinasi Video

\begin{tabular}{cc}
\hline Persentase Keterlaksanaan & Kriteria Keterlaksanaan \\
\hline $85 \%<P T \leq 100 \%$ & Sangat baik \\
$70 \%<P T \leq 85 \%$ & Baik \\
$55 \%<P T \leq 70 \%$ & Cukup baik \\
$40 \%<P T \leq 55 \%$ & Kurang baik \\
$P T \leq 40 \%$ & Tidak baik \\
\hline
\end{tabular}

(Muttaqin \& Azmi, 2020)

Data hasil observasi aktivitas siswa dianalisis dengan aturan berikut (Muttaqin \& Azmi, 2020).

$$
P A=\frac{m}{M} \times 100 \%
$$

Keterangan : $P A$ : Persentase keaktifan siswa

$m$ : Jumlah skor yang diperoleh seluruh siswa

$M$ : Jumlah skor maksimal seluruh siswa 
Adapun kriteria aktivitas siswa ditunjukkan dalam tabel berikut.

Tabel 2 Kriteria Keterlaksanaan Pembelajaran Discovery Learning Kombinasi Video

\begin{tabular}{cc}
\hline Persentase Keterlaksanaan & Kriteria Keterlaksanaan \\
\hline $85 \%<P T \leq 100 \%$ & Sangat baik \\
$70 \%<P T \leq 85 \%$ & Baik \\
$55 \%<P T \leq 70 \%$ & Cukup baik \\
$40 \%<P T \leq 55 \%$ & Kurang baik \\
$P T \leq 40 \%$ & Tidak baik \\
\hline
\end{tabular}

(Muttaqin \& Azmi, 2020)

Data hasil belajar siswa dianalisis berdasarkan KKM. KKM yang ditetapkan di SMP Negeri 2 Peterongan pada tahun pelajaran 2020/2021 adalah 75 . Secara individu siswa dikatakan tuntas jika mencapai skor minimal 75. Selanjutnya persentase siswa yang tuntas secara klasikal dianalisis aturan berikut.

$$
P K=\frac{t}{T} \times 100 \%
$$

Keterangan : $P K$ : Persentase ketuntasan belajar klasikal

$t$ : Jumlah siswa yang tuntas

$T$ : Jumlah seluruh siswa

Apabila persentase ketuntasan siswa secara klasikal sudah mencapai 80\% berarti hasil belajar pada materi bangun ruang sisi lengkung sudah sesuai dengan yang diharapkan. Indikator keberhasilan dalam penelitian ini adalah sebagai berikut.

1. Aktivitas guru dan aktivitas siswa selama pembelajaran berada pada kategori minimal baik.

2. Ketuntasan hasil belajar siswa secara klasikal tercapai. Hasil belajar dikatakan tuntas secara klasikal apabila persentase banyaknya siswa yang tuntas secara individu telah mencapai $\geq 80 \%$. Siswa dikatakan tuntas secara individu apabila memperoleh skor hasil tes $\geq 75$.

\section{Hasil dan Pembahasan}

Pelaksanaan penelitian pada setiap siklus meliputi tahapan-tahapan: (1) perencanaan, (2) pelaksanaan, (3) pengamatan, dan (4) refleksi.

\section{Siklus I}

(1) Tahap perencanaan

Pada tahap ini disiapkan : RPP yang sesuai dengan model discovery learning kombinasi video, materi ajar tentang luas permukaan dan volume tabung, 
video pembelajaran, Lembar Kerja Siswa (LKS), lembar observasi aktivitas guru dan siswa, serta soal tes.

(2) Tahap pelaksanaan

Tahap pelaksanaan dilakukan sebanyak 3 pertemuan, yaitu 2 pertemuan pembelajaran dan 1 pertemuan untuk pemberian tes. Pertemuan ke-1 pada hari Sabtu, 6 Februari 2021, pertemuan ke-2 pada hari Selasa, 9 Februari 2021. Pertemuan ke-3 adalah pemberian tes, pada tanggal 13 Februari 2021.

(3) Tahap pengamatan

Tahap pengamatan melibatkan 2 guru yang bertindak sebagai observer yaitu Observer 1 yang mengamati aktivitas guru dalam menerapkan discovery learning kombinasi video dan observer 2 sebagai pengamat aktivitas siswa. Hasil pengamatan menunjukkan bahwa persentase keterlaksanaan aktivitas guru dalam mengelola pembelajaran discovery learning kombinasi video sebesar 79\%, yang termasuk kategori baik. Hasil observasi keaktifan siswa dalam mengikuti kegiatan pembelajaran dengan penerapan discovery leraning kombinasi video pada siklus 1 menunjukkan kategori cukup dengan persentase $67 \%$.

(4) Tahap refleksi

Tahap refleksi menunjukkan bahwa siswa jarang bertanya dan kurang aktif berdiskusi. Berdasarkan hasil observasi dan evaluasi, pelaksanaan tindakan siklus I belum mencapai indikator keberhasilan yang telah ditetapkan dengan persentase ketuntasan klasikal masih menunjukkan 75\%. Artinya, di siklus 1 belum memenuhi indikator keberhasilan, sehingga berlanjut ke siklus 2 . Selanjutnya dilakukan perencanaan tindakan siklus 2. Kekurangan-kekurangan yang terdapat pada siklus 1 akan diperbaiki pada siklus 2. Berdasarkan hasil refleksi, maka pada siklus selanjutnya guru harus: a) memotivasi siswa dengan memberikan contoh manfaat materi pada kehidupan nyata; b) memberi rangsangan yang lebih menarik, bisa berupa gambar atau video, tidak sekedar berupa pertanyaan; c) memberi bimbingan saat siswa mengerjakan LKS dan memfasilitasi siswa yang bertanya melalui chat whatsapp pribadi.

\section{Siklus 2}

(1) Tahap perencanaan

Pada tahap perencanaan disiapkan : RPP berisi rancangan discovery learning kombinasi video yang telah diperbaiki berdasarkan hasil refleksi di siklus 1, ma- 
teri ajar tentang luas permukaan dan volume tabung, video pembelajaran, LKS, lembar observasi aktivitas guru dan siswa, serta tes hasil belajar.

(2) Tahap pelaksanaan

Siklus 2 memuat 3 pertemuan, yaitu 2 pertemuan pembelajaran dan 1 pertemuan untuk tes hasil belajar akhir siklus. Pertemuan pembelajaran ke-1 dilaksanakan pada hari Selasa tanggal 16 Februari 2021, pertemuan ke-2 dilaksanakan pada hari Sabtu tanggal 20 Februari 2021, dan pertemuan ke-3 digunakan untuk tes.

(3) Tahap pengamatan

Hasil pengamatan aktivitas guru dalam penerapan discovery learning kombinasi video menunjukkan persentase $86 \%$ kategori sangat baik. Hasil pengamatan aktivitas siswa selama penerapan discovery learning kombinasi video menunjukkan persentase $86 \%$ dengan kategori sangat baik. Setelah pelaksanaan tindakan siklus 2 selama 2 kali pertemuan, diadakan tes hasil belajar tentang materi luas dan volume kerucut yang dilaksanakan pada hari Selasa tanggal 23 Februari 2021 yang diikuti oleh 32 siswa.

(4) Tahap refleksi

Pada tindakan siklus 2 ini penerapan model pembelajaran discovery learning kombinasi video telah mengalami peningkatan. Hasil observasi menunjukkan bahwa aktivitas guru dan siswa berada pada kategori sangat baik. Ketuntasan belajar secara klasikal mencapai 88\%. Ini menunjukkan indikator keberhasilan telah tercapai. Sehingga penelitian ini telah berhasil dilaksanakan sesuai rencana pelaksanaan penelitian dengan dua siklus tindakan.

Berdasarkan hasil penelitian pada siklus 1 dan siklus 2 dapat diketahui bahwa pembelajaran dengan penerapan discovery learning kombinasi video dapat meningkatkan aktivitas guru, aktivitas siswa dan hasil belajar matematika siswa. Perbandingan hasil observasi terhadap aktivitas guru dalam penerapan discovery learning kombinasi video pada siklus 1 dan siklus 2 dapat dilihat pada Tabel 3.

Tabel 3 Perbandingan Persentase Aktivitas Guru Antara Siklus 1 dan Siklus 2

\begin{tabular}{llll}
\hline & \multirow{2}{*}{ Aspek aktivitas guru yang dinilai } & \multicolumn{2}{c}{ Persentase } \\
\cline { 3 - 4 } & & Siklus 1 & Siklus 2 \\
\hline A & Kegiatan Pendahuluan & $88 \%$ & $100 \%$ \\
\hline 1 & Mengucap salam dan mengajak siswa berdo'a & $88 \%$ & $100 \%$
\end{tabular}




\begin{tabular}{|c|c|c|c|}
\hline & \multirow{2}{*}{ Aspek aktivitas guru yang dinilai } & \multicolumn{2}{|c|}{ Persentase } \\
\hline & & \multirow{2}{*}{$\begin{array}{l}\text { Siklus } 1 \\
63 \%\end{array}$} & \multirow{2}{*}{$\begin{array}{r}\text { Siklus 2 } \\
75 \%\end{array}$} \\
\hline 3 & $\begin{array}{l}\text { Memotivasi siswa dan mengaitkan pembelajaran dengan } \\
\text { pengetahuan awal siswa }\end{array}$ & & \\
\hline 4 & $\begin{array}{l}\text { Meminta siswa mengisi daftar hadir melalui linkgoogle } \\
\text { forms }\end{array}$ & $100 \%$ & $100 \%$ \\
\hline B & Kegiatan Inti & & \\
\hline 5 & $\begin{array}{l}\text { Fase 1: Pemberian rangsangan } \\
\text { Guru memberi rangsangan dan mengajukan pertanyaan }\end{array}$ & $63 \%$ & $63 \%$ \\
\hline 6 & $\begin{array}{l}\text { Fase 2: Identifikasi Masalah } \\
\text { Guru meminta siswa untuk mengajukan pertanyaan ber- } \\
\text { kaitan dengan permasalahan yang disampaikan guru }\end{array}$ & $75 \%$ & $75 \%$ \\
\hline 7 & $\begin{array}{l}\text { Fase 3: Pengumpulan data } \\
\text { Guru memberi kesempatan siswa untuk membaca berba- } \\
\text { gai sumber dan mengirim video youtube melalui link }\end{array}$ & $75 \%$ & $75 \%$ \\
\hline 8 & $\begin{array}{l}\text { Fase 4: Pengolahan Data } \\
\text { Guru membimbing siswa saat siswa mengolah data }\end{array}$ & $63 \%$ & $75 \%$ \\
\hline 9 & $\begin{array}{l}\text { Fase 5: Pembuktian } \\
\text { Guru meminta siswa berdiskusi melalui forum google } \\
\text { classroom atau grup WA }\end{array}$ & $75 \%$ & $75 \%$ \\
\hline 10 & $\begin{array}{l}\text { Fase 6: Menarik Kesimpulan } \\
\text { Guru mengajak siswa untuk membuat kesimpulan }\end{array}$ & $75 \%$ & $100 \%$ \\
\hline $\mathbf{C}$ & Kegiatan Penutup & & \\
\hline 11 & Meminta siswa melakukan refleksi kegiatan & $75 \%$ & $75 \%$ \\
\hline 12 & $\begin{array}{l}\text { Menginformasikan materi berikutnya atau pemberian tu- } \\
\text { gas rumah }\end{array}$ & $88 \%$ & $100 \%$ \\
\hline 13 & Menutup pelajaran dengan mengucap salam & $100 \%$ & $100 \%$ \\
\hline & lah Skor & $1025 \%$ & $1113 \%$ \\
\hline & lah Skor Maksimal & $1300 \%$ & $1300 \%$ \\
\hline & sentase & $79 \%$ & $\mathbf{8 6 \%}$ \\
\hline
\end{tabular}

Hasil observasi terhadap aktivitas guru dalam pembelajaran mencapai 79\% pada siklus 1 yang menunjukkan kategori baik. Sedangkan pada siklus 2 meningkat menjadi $86 \%$ dengan kategori sangat baik. Melalui pembelajaran discovery learning kombinasi video, peran guru dapat diubah dari "teacher centered" menjadi "student centered". Sehingga pembelajaran menjadi lebih bermakna dan siswa dapat lebih berperan dalam proses pembelajaran. Perban- 
dingan hasil observasi terhadap aktivitas siswa selama pembelajaran dengan penerapan discovery learning kombinasi video pada siklus 1 dan siklus 2 dapat dilihat pada tabel berikut.

Tabel 4 Perbandingan Persentase Aktivitas Siswa Antara Siklus 1 dan Siklus 2

\begin{tabular}{llcc}
\hline \multirow{2}{*}{ Aspek yang Dinilai } & \multicolumn{2}{c}{ Persentase } \\
\cline { 2 - 3 } & Siklus 1 & Siklus 2 \\
\hline 1 & Siswa mengisi daftar hadir melalui tautan googleforms & $88 \%$ & $100 \%$ \\
2 & $\begin{array}{l}\text { Siswa mengamati stimulus dari guru (dilihat dari banyak } \\
\text { siswa yang melihat pertanyaan/ stimulus) }\end{array}$ & $75 \%$ & $75 \%$ \\
3 & Siswa mengajukan pertanyaan & $38 \%$ & $63 \%$ \\
4 & Siswa membaca buku dan menonton vido yang dibagikan & $75 \%$ & $100 \%$ \\
& guru & $75 \%$ & $100 \%$ \\
5 & Siswa mengolah data dengan mengerjakan lembar kerja & $38 \%$ & $75 \%$ \\
6 & Siswa berdiskusi di forum google classroom atau grup w.a & $75 \%$ & $75 \%$ \\
7 & Siswa membuat rangkuman di buku catatan & $75 \%$ & $100 \%$ \\
8 & Siswa mengirim hasil tugas & $\mathbf{5 3 8 \%}$ & $\mathbf{6 8 8 \%}$ \\
\hline Jumlah Skor & $\mathbf{8 0 0 \%}$ & $\mathbf{8 0 0 \%}$ \\
\hline Jumlah Skor Maksimal & $\mathbf{6 7 \%}$ & $\mathbf{8 6 \%}$ \\
\hline Persentase & & \\
\hline
\end{tabular}

Hasil observasi terhadap aktivitas siswa dalam pembelajaran pada siklus 1 mencapai 67\% yang menunjukkan kategori cukup baik. Sedangkan pada siklus 2 meningkat menjadi 86\% dengan kategori sangat baik. Melalui pembelajaran discovery learning kombinasi video, siswa memperoleh pengetahuan dengan menemukan konsep sendiri sehingga ingatan siswa bisadapat bertahan lebih lama.

Pada siklus 1, ketuntasan belajar siswa secara klasikal hanya mencapai 75\% (24 siswa yang telah memperoleh nilai minimal 75). Hasil tes siklus 1 mengalami peningkatan 16\% dari hasil tes pra penelitian. Persentase ketuntasan klasikal pada siklus 2 mencapai 88\%, yang menunjukkan adanya peningkatan sebesar 13\% dari siklus 1. Karena aktivitas guru dalam mengelola pembelajaran dengan discovery learning kombinasi video berada pada kategori sangat baik, aktivitas siswa selama penerapan discovery learning kombinasi video berada pada kategori sangat baik, serta ketuntasan hasil belajar siswa secara klasikal tercapai maka penelitian ini dihentikan setelah siklus kedua.

Hasil observasi aktivitas guru, aktivitas siswa, dan hasil belajar siswa selama penelitian ini ditunjukkan pada diagram berikut. 


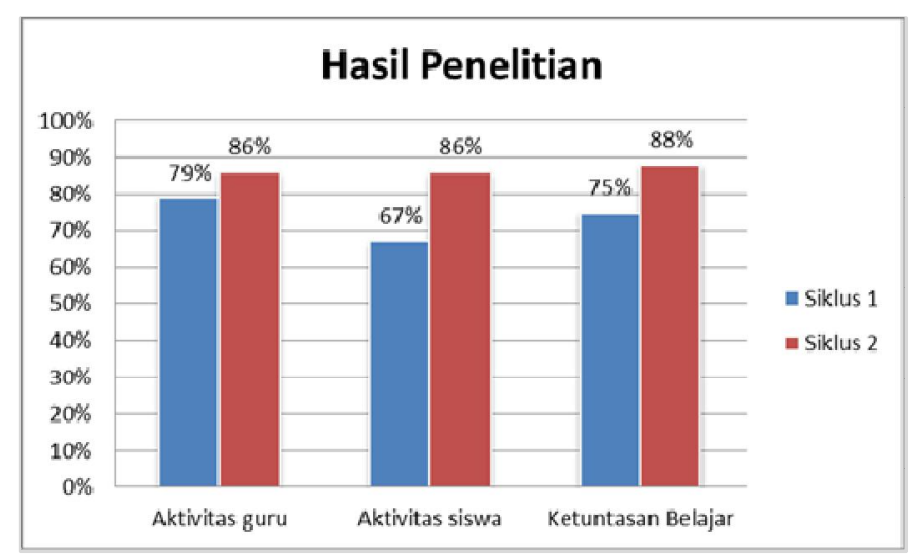

Gambar 1. Diagram Hasil Penelitian

Gambar 1 menunjukkan bahwa terjadi peningkatan pada aktivitas guru, aktivitas siswa, dan ketuntasan belajar (klasikal) dari siklus 1 ke siklus 2. Hasil tersebut menunjukkan bahwa dengan discovery learning kombinasi video, siswa dapat belajar lebih maksimal sehingga meningkatkan hasil belajarnya. Hasil tersebut sejalan dengan yang disampaikan oleh Fajri (2019) bahwa discovery learning dapat membuat siswa belajar dengan baik dan lancar, sehingga meningkatkan hasil belajarnya.

Selanjutnya penggunaan discovery learning dapat dikembangkan tidak hanya meningkatkan hasil belajar siswa tetapi juga untuk meningkatkan kemampuan berpikirnya. Hal ini sesuai hasil penelitian Cintia et al. (2018) yang menunjukkan bahwa penerapan discovery learning dapat meningkatkan kemampuan berpikir kreatif siswa, kemampuan berpikir kreatif siswa, dan hasil belajar dalam pembelajaran tematik di kelas V SDN Sidorejo Kidul 02 Tingkir. Selain itu discovery learning juga dapat diterapkan pada mata pelajaran lain, misalnya IPA (Rosarina, Sudin,\& Sujana, 2016)

\section{Kesimpulan}

Berdasarkan hasil penelitian dapat disimpulkan bahwa penerapan discovery learning kombinasi video dapat meningkatkan hasil belajar matematika siswa di kelas IX dalam dua siklus pembelajaran pada materi bangun ruang sisi lengkung. Selanjutnya discovery learning kombinasi video juga dapat dicobakan pada materi lain dan di tingkatan kelas yang berbeda guna memperbaiki mutu pembelajaran dan hasil yang diperoleh siswa. 


\section{Daftar Pustaka}

Adhar, E. L. (2012). Pembelajaran Matematika dengan Metode Penemuan Terbimbing Untuk Meningkatkan Kemampuan Representasi dan Pemecahan Masalah Matematis Siswa SMP. Jurnal Penelitian Pendidikan, 13(2), 1-10. http:/ / jurnal.upi.edu/ file/ Leo_Adhar.pdf

Anam, Khoirul. (2016). Pembelajaran Berbasis Inkuiri: Metode dan Aplikasi. Yogyakarta: Pustaka Belajar.

Ariyana, Yoki, dkk. (2019). Buku Pegangan Pembelajaran Berorientasi pada Keterampilan Berpikir Tingkat Tinggi. Jakarta: Direktorat Jenderal Guru dan Tenaga Kependidikan Kementrian Pendidikan dan Kebudayaan

Cintia, N. I., Kristin, F., \& Anugraheni, I. (2018). Penerapan Model Pembelajaran Discovery Learning Untuk Meningkatkan Kemampuan Berpikir Kreatif Dan Hasil Belajar Siswa. Perspektif Ilmu Pendidikan, 32(1), 67-75. https:// doi.org/ 10.21009/ pip.321.8

Fajri, Z. (2019). Model Pembelajaran Discovery Learning Dalam Meningkatkan Prestasi Belajar Siswa Sd. Jurnal IKA PGSD (Ikatan Alumni PGSD) UNARS, 7(2), 1. https:/ / doi.org/ 10.36841/ pgsdunars.v7i2.478

Hosnan. 2014. Pendekatan Saintifik dan Kontekstual dalam Pembelajaran Abad 21. Bogor: Ghalia Indonesia.

Kristin, F. (2016). Analisis Model Pembelajaran Discovery Learning Dalam Meningkatkan Hasil Belajar Ipa-Biologi. Jurnal Pendidikan Dasar PerKhasa, 2(1). https:// doi.org/ 10.32734/ st.v2i2.532

Maf'ulah, S., \& Juniati, D. (2019). Students' Strategies to Solve Reversible Problems of Function: The Part of Reversible Thinking. Journal of Physics: Conference Series, 1417(1). https:// doi.org/ 10.1088/ 1742-6596/ 1417/ 1/ 012051

Maf'ulah, S., \& Juniati, D. (2020). Exploring reversible thinking of preservice mathematics teacher students through problem-solving task in algebra. Journal of Physics: Conference Series, https:/ / doi.org/ 10.1088/ 1742-6596/ 1663/ 1/ 012003

Muttaqin, M. Z. H., \& Azmi, I. (2020). Penerapan Problem Based Learning Berbasis LessonStudy Untuk Meningkatkan Keaktifan Dan Hasil Belajar Kognitif Siswa Kelas X Mia Madrasah Aliyah Muhammadiyah 1 Malang Tahun Pelajaran 2014/ 2015 Pada Mata Pelajaran Biologi. Jurnal Ilmiah Global Education, 1(2), 10-18. 
Pangaribowo, D. R., Keliat, N. R., Sastrodihardjo, S., \& Hutangoal, D. R. (2017). Penerapan model Pembelajaran Discovery Learning dan Permainan Smart Case untuk Meningkatkan Hasil Belajar Siswa Kelas VII C SMP Kristen 2 Salatiga The Application of Discovery Learning Model and Smart Case Game to Improve Students ' Learning Results of St. Bioedukasi, 10(1), 47-57.

Prastowo, Andi. (2012). Panduan Kreatif Membuat Bahan Ajar Inovatif. Yogyakarta: Diva Press.

Rosarina, Gina; Sudin, Ali; Sujana, A. (2016). Penerapan Model Discovery Learning Untuk Meningkatkan Hasil Belajar Siswa Kelas Ix Pada Pembelajaran Ipa. BIO EDUCATIO: (The Journal of Science and Biology Education), 5(2), 371-380. https:// doi.org/ 10.31949/ be.v5i2.2597

Widiadnyana, I., Sadia, M., \& Suastra, M. (2014). Pengaruh Model Discovery Learning Terhadap Pemahaman Konsep Ipa Dan Sikap Ilmiah Siswa Smp. Jurnal Pendidikan Dan Pembelajaran IPA Indonesia, 4(2).

Yudianto, A. (2017). Penerapan Video Sebagai Media Pembelajaran. Seminar Nasional Pendidikan 2017, 234-237.

Yuliana, N. (2019). Penggunaan Model Pembelajaran Discovery Learning Dalam Peningkatan Hasil Belajaran Siswa Di Sekolah Dasar. Pedagogi: Jurnal Ilmu Pendidikan, 18(2), 56. https:/ / doi.org/ 10.24036/ fip.100.v18i2.318.000-000 